\title{
EFEKTIVITAS PEMBELAJARAN \\ MODEL ALLAN G. BLUMAN DALAM PENINGKATAN \\ PEMAHAMAN KONSEP MATEMATIKA MAHASISWA
}

\author{
Bambang Priyo Darminto \\ FKIP Universitas Muhammadiyah Purworejo \\ (e-mail: darmintobambangpriyo@yahoo.co.id; HP: 081804380770)
}

\begin{abstract}
The Effectiveness of Allan B. Bluman's Learning Model in the Improvement of Students' Understanding of Mathematical Concepts. Understanding mathematical concepts is one of the important academic aspects. This study aims to improve students' skills in connecting, communicating and applying mathematical concepts to solve mathematical problems in everyday life. This was an experimental study using the pretest-posttest control group design. The sample consisted of 77 students. The control group learned through the expository method, whereas the experimental group learned through a step by step approach using an interactive multimedia application program of Allan G. Bluman's model. The results showed that the gain of the experimental group was significantly higher than that of the control group. It can be concluded that the computer-based learning based on Allan G. Bluman's model enhances the understanding of mathematical concepts.
\end{abstract}

Keywords: mathematical concepts, academic aspect, step by step approach, interactive multimedia, Allan G. Bluman's model

\section{PENDAHULUAN}

Berdasarkan Undang-Undang Republik Indonesia Nomor 14 Tahun 2005 tentang Guru dan Dosen, setiap guru atau dosen harus memiliki empat kompetensi, yaitu kompetensi profesional, kompetensi pedagogis, kompetensi sosial, dan kompetensi kepribadian. Sehubungan dengan hal tersebut, sudah selayaknya setiap calon guru harus dibekalikemampuan dan keterampilan yang berkaitan dengan empat kompetensi tersebut agar mereka memiliki kemampuan profesional dan daya saing yang tinggi.

Lembaga pendidkan tinggi yang memiliki fakultas kependidikan mempu- nyai peran yang amat strategis dalam menciptakan guru-guruatau dosen yang profesional dan berdaya saing tinggi. Salah satu laporan Bank Dunia tahun 1999, dinyatakan bahwa terdapat kontribusi yang signifikan dari sektor pendidikan tinggi terhadap upaya peningkatan daya saing bangsa (Depdiknas, 2004:4). Berdasarkan hal tersebut, Departemen Pendidikan Nasional saat ini telah menyusun rencana strategis guna meningkatkan mutu lulusan perguruan tinggi, yakni lulusan yang terampil, kreatif dan inovatif dalam memanfaatkan ilmu pengetahuan dan teknologi, ahli, profesional, serta memiliki kecakapan hidup yang dapat membantu 
dirinya dalam menghadapi berbagai tantangan dan perubahan (Depdiknas, 2005:9). Sehubungan dengan hal tersebut, pemerintah telah membuat beberapa program yang diharapkan dapat dilaksanakan oleh lembaga pendidikan, antara lain: peningkatan kemampuan tenaga pengajar, penyediaan sarana dan prasarana belajar yang lebih memadai, mengembangkan kurikulum yang lebih tepat, memperbanyak sumber dan bahan ajar, menciptakan berbagai macam model-model pembelajaran, serta meningkatkan penguasaan information communication technology (ICT).

Seiring dengan semakin pesatnya perkembangan teknologi informasi dan komunikasi, saat ini model-model pembelajaran telah dapat dilakukan melaui pemberdayaan teknologi komputer. Model pembelajaran berbasis komputer merupakan suatu pembelajaran yang berlandaskan pada konsep ComputerBased Instruction (CBI) maupun Computer-Assisted Instruction (CAI). Pada awalnya, program aplikasi komputer yang digunakan dalam CBI atau CAI dikembangkan berdasarkan teori perilaku, namun sekarang telah dikembangkan berdasarkan teori kognitif sehingga beberapa program aplikasi telah dibuat berlandaskan tingkat kemampuan dan kesiapan belajar anak. Untuk meningkatkan minat dan daya tarik, program pembelajaran berbasis komputer dibuat lebih menarik, interaktif, menggabungkan konsep visual, grafis, dan audio, serta mudah dioperasikan. Beberapa penelitian tentang penggunaan komputer dalam pembelajaran matematika telah menunjukkan adanya peningkatan kemampuan berpikir matematis, kreativi- tas, dan transfer keterampilan matematika. Sarama dan Clements (2001:3) menjelaskan bahwa keterampilan berpikir pada anak dapat ditingkatkan melalui pembelajaran berbantuan komputer karena dalam proses mengkonstruksi pengetahuannya, tidak jarang para siswa melakukan manipulasi dan kreasi dengan mengoperasikan komputer. Di sisi lain, Yushua, et al. (2003:3) menyatakan bahwa pembelajaran matematika yang menggunakan alat bantu komputer dapat menumbuhkembangkan kreativitas siswa dan meningkatkan kontribusi skills terhadap keterampilan kognitif. Dalam perkuliahan di perguruan tinggi, Hillel (2001:2) menyatakan bahwa penggunaan komputer sangat bermanfaat untuk meningkatkan kreativitas mahasiswa dalam menemukan solusi permasalahan, meningkatkan logika dan mengembangkan konsep-konsep matematis.

Pemahaman konsep matematis merupakan salah satu aspek akademis yang sangat penting dimiliki oleh seorang guru matematika. Oleh karena itu, upaya peningkatan kecakapan ini perlu terus ditingkatkan. Pemahaman konsep matematis merupakan kecakapan atau kemahiran matematis yang diharapkan dapat tercapai dalam belajar matematika yaitu dengan menunjukkan keterkaitan antarkonsep dan mengaplikasikan konsep atau algoritma secara luwes, akurat, efisien, dan tepat dalam pemecahan masalah (Depdiknas, 2003: 2). Derajat pemahaman konsep ditentukan oleh tingkat keterkaitan antara gagasan, prosedur, dan pemecahan masalah. Sehubungan dengan hal tersebut, maka pemahaman konsep merupakan kompetensi yang harus dimiliki maha- 
siswa dengan beberapa indikator, seperti: (1) menyatakan atau menjelaskan ulang sebuah konsep; (2) mengklasifikasikan sifat-sifat tertentu; (3) memberi contoh; (4) merepresentasikan konsep; (5) menggunakan konsep untuk menyelesaikan masalah. Menurut Skemp dan Pollatsek (Sumarmo, 1987:24), pemahaman konsep terbagi dalam dua jenis, yaitu pemahaman instrumental dan pemahaman rasional. Pemahaman instrumental merupakan pemahaman konsep yang saling terpisah dan hanya rumusrumus yang dihafal untuk melakukan perhitungan sederhana, sedangkan pemahaman rasional merupakan pemahaman skema atau struktur yang digunakan untuk menyelesaikan masalah yang lebih luas dalam kehidupan sehari-hari. Kedua jenis pemahaman konsep ini harus dimiliki oleh guru matematikaagarmampu melaksanakan pembelajaran yang sebaik-baiknya.

Berdasarkan hasil observasi peneliti, prestasi akademik mahasiswa Program Studi Pendidikan Matematika di Universitas Muhammadiyah Purworejo dalam aspek pemahaman konsep matematis masih perlu ditingkatkan. Berdasarkan hasil-hasil ujian akhir semester selama 5 tahun terakhir, diperoleh data bahwa soal-soal ujian, khususnya dalam aspek penerapan konsep untuk memecahkan masalah, umumnya tidak dapat diselesaikan dengan baik oleh mahasiswa. Hal ini mungkin diakibatkan oleh kurangnya pemahaman konsep matematis dariparamahasiswa. Oleh karenaitu, upaya peningkatan pemahaman konsep matematis kepada para mahasiswa perlu dilakukan dengan sungguh- sungguh sehingga kemampuan profesional mereka menjadi lebih baik.

Salah satu mata kuliah yang berperan dalam membantu memecahkan beberapa persoalan sehari-hari adalah Statistika. Beberapa orang menyatakan bahwa statistika merupakan bagian dari matematika. Dengan demikian, pengertian konsep matematis dapat diperoleh dari pengetahuan statistika. Dalam banyak hal, konsep matematis yang dimilikioleh statistika sangat berguna untuk memecahkan masalah yang muncul dalam kehidupan sehari-hari. Di samping itu, metodologi statistika telah banyak digunakan dalam banyak bidang ilmu pengetahuan dan engineering. Mayers L.S, et al. (2002:14) mengemukakan bahwa " ... there are many case studies that demonstrate statistical analysis of interesting real life data sets". Karena peranannya sangat penting, baik dalam pengembangan ilmu pengetahuan dan membantu memecahkan masalah kehidupan manusia, statistika menjadi mata kuliah yang sangat penting diajarkan di perguruan tinggi. Melalui pembelajaran statistika, kemampuan pemahaman konsepmatematis mahasiswa sangat mungkin untuk ditingkatkan.

Penelitian ini dilaksanakan dengan tujuan pokok meningkatkan kecakapan mahasiswa dalam mengaitkan, mengkomunikasikan dan menerapkan konsep-konsep matematika untuk memecahkan masalah matematis dalam kehidupan sehari-hari. Dalam penelitian ini, kemampuan konsep matematis calon guru matematika diupayakan dapat ditingkatkan melalui pembelajaran berbasis komputer dalam mata kuliah Statistika. Untuk mengupayakan pening- 
katan kemampuan konsep matematis tersebut, kelompok kontrol diberi pembelajaran dengan metode ekspositori, sedangkan kelompok eksperimen diajar dengan menggunakan program aplikasi multimedia interaktif Elementary Statistics, A Step by Step Approach for Higher Education. Program aplikasi multimedia interaktif ini dibuat oleh Allan G. Bluman. Oleh karena itu, pendekatan pembelajaran kelompok eksperimen dalam penelitian ini dinamakan pendekatan Step by Step model Allan G. Bluman.

Pendekatan Step by Step model Allan G. Bluman yang implementasinya menggunakan program aplikasi multimedia berbasis komputer sangat menarik untuk digunakan dalam pembelajaran. Model ini sangat cocok dilaksanakan dalam pembelajaran matematika di perguruan tinggi karena di samping dapat meningkatkan kemandirian belajar (self regulated learning), model pembelajaran ini dapat meningkatkan inovasi dan kreativitas. Dalam kemandirian belajar terdapat beberapa karakteristik yang dapat dikembangkan, yakni: (1) mahasiswa dapat merancang sendiri belajarnya; (2) mahasiswa dapat menentukan sendiri strategi dan rancangan belajarnya; (3) mahasiswa dapat mengatur waktu belajarnya sendiri; dan (4) mahasiswa dapat memantau kemajuan belajarnya sendiri, mengevaluasi hasil belajarnya sendiri, dan membandingkan dengan standar tertentu.

Program aplikasi multimedia interaktif model Allan G. Bluman memiliki beberapa keunggulan, antara lain:(1) topik-topik bahasan dalam program aplikasi sebagian besar sesuai dengan pokok bahasan dalam kurikulum Program
Studi Pendidikan Matematika di Universitas Muhammadiyah Purworejo; (2) secara umum materi yang disajikan diatur mulai dari hal-hal yang paling sederhana dan mudah menuju ke hal-hal yang kompleks dan rumit; (3) penyajian materi sangat menarik dan interaktif, serta disajikan contoh-contoh soal guna memberi kesempatan mahasiswa (user) untuk berkreasi; (4) penyajian contoh soal sangat variatif dan masing-masing diberikan solusinya; (5) ketersediaan soal latihan cukup banyak (lebih dari 200 soal); (6) jika mahasiswa mengalami kesulitan dalam belajar atau kesulitan dalam mengerjakan soal latihan, mereka dapat melihat secara bertahap tentang cara-cara menyelesaikan soal dimaksud (melalui menu Show Me).

Berdasarkan latar belakang yang telah diuraikan di atas, peneliti memperoleh inspirasi untuk mengaplikasikan komputer sebagai alat bantu dalam proses pembelajaran matematika di PTM sebagai salah satu upaya meningkatkan pemahaman konsep dasar matematika mahasiswa. Untuk melihat efektivitas dan kehandalan model pembelajaran berbasis komputer model Allan G. Bluman, prosespelaksanaan pembelajaran dalam penelitian ini dirancang sebagai berikut.

- Kelompokeksperimen:kelompokmahasiswa yang diajar dengan menggunakan program aplikasi multimedia interaktif Elementary Statistics, A Step by Step Approach for Higher Education berbasis komputer buatan Allan G. Bluman.

- Kelompok kontrol: kelompok mahasiswa yang diajar tanpa menggunakan alat bantu komputer, dilaksana- 
kan di kelompok dengan metode ceramah/ekspositori (konvensional).

Perhatian penelitian ini difokuskan pada penerapan model pembelajaran matematika berbasis komputer, namun level kemampuan awal (tinggi dan rendah) daripara mahasiswa juga ikut diperhatikan sebab untuk meningkatkan pemahaman konsep, mahasiswa akan dihadapkan pada sejumlah tugas/permasalahan matematika yang penyelesaiannya memerlukan sejumlah pengetahuan awal matematika. Berdasarkan uraian di atas, permasalahan pokok dalam penelitian ini sebagai berikut: Apakah terdapat perbedaan yang signifikan mengenaipeningkatan pemahamankonsep antara mahasiswa yang diajar dengan model eksperimen dan konvensional?

Penelitian ini mempunyai beberapa manfaat, antara lain seperti berikut.

- Bagi mahasiswa, pembelajaran berbasis komputer bermanfaat untuk meningkatkan minat, daya tarik, dan aktivitas/keterlibatan mahasiswa dalam proses pembelajaran.

- Bagi dosen, pembelajaran berbasis komputer bermanfaat untuk kegiatan remediasi dan penguatan (reinforcement).

- Bagi lembaga atau penentu kebijakan (decision maker), pembelajaran berbasis komputer bermanfaat dapat digunakan sebagai salah satu daya tarik sehingga dapat meningkatkan kepercayaan masyarakat untuk memilih PTM sebagai tempat belajar.

\section{METODE}

Populasi penelitian ini adalah seluruh mahasiswa semester I tahun 2009/
2010 sebanyak 348 orang pada Program Studi Pendidikan Matematika Universitas Muhammadiyah Purworejo. Dari 348 orang, diambil 77 orang secara random sebagai sampel penelitian dan ditabulasikan secara alfabetis. Sampel yang bernomor genap, yakni sebanyak 38 orang, diambil sebagai kelompok eksperimen, sedangkan sampel yang bernomor ganjil digunakan sebagai kelompok kontrol. Penelitian ini merupakan penelitian eksperimen dengan desain kelompok pretes-postes (pretest-postest control group design). Dalam desain ini, sampel diambil secara acak (A), pemahaman konsep matematis awal diukur dengan pretes $(\mathrm{O})$, dan setelah diberi perlakuan berbeda kemudian diukur pemahaman konsep matematis akhir dengan postes (O). Kelompok eksperimen memperoleh perlakuan $X$, sedangkan kelompok kontrol tidak diberi perlakuan. Desain penelitian ini disajikan sebagai berikut.

$\begin{array}{llll}\text { A } & O & X & O \\ A & O & & O\end{array}$

Keterangan:

A : Pemilihan sampel secara acak

$\mathrm{O}$ : Pretes atau postes

X : Model pembelajaran Allan G. Bluman

Skema desain faktorial penelitian ini, disajikan pada Tabel 1 di bawah ini.

Tabel 1. Skema Desain Penelitian

\begin{tabular}{ccc} 
KAM & \multicolumn{2}{c}{ Pemahaman Konsep Mahasiswa } \\
\cline { 2 - 3 } & Kel. Eksperimen & Kel. Kontrol \\
Tinggi & $\mu_{E T}$ & $\mu_{K T}$ \\
Sedang & $\mu_{E S}$ & $\mu_{K S}$ \\
Rendah & $\mu_{E R}$ & $\mu_{K R}$ \\
\hline
\end{tabular}


Keterangan:

KAM : Kemampuan Awal Mahasiswa.

$\mu_{E T}$ : Rata-rata skor pemahaman konsep matematis kelompok tinggi pada kelompok eksperimen.

$\mu_{E S} \quad$ : Rata-rata skor pemahaman konsep matematis kelompok sedang pada kelompok eksperimen.

$\mu_{E R} \quad$ : Rata-rata skor pemahaman konsep matematis kelompok rendah pada kelompok eksperimen.

$\mu_{K T} \quad$ : Rata-rata skor pemahaman konsep matematis kelompok tinggi pada kelompok kontrol.

$\mu_{K S} \quad$ : Rata-rata skor pemahaman konsep matematis kelompok sedang pada kelompok kontrol.

$\mu_{K R} \quad$ : Rata-rata skor pemahaman konsep matematis kelompok rendah pada kelompok kontrol.

Secara umum, kemampuan awal mahasiswa dapat dikategorikan ke dalam tiga kelompok, yakni kelompok rendah (lower group), kelompok sedang (middle group), dan kelompok tinggi (upper group).

Pengelompokan tersebut didasarkan pada hasil skor pretes setiap mahasiswa dengan skor ideal sama dengan 60. Penentuan skor ideal ini diperoleh dari banyaknyaitem soal dikalikan skor mak- simal, yakni 10. Karena banyaknya soal ada 6 item, maka skor idealnya 60 . Prosedur analisis data dan uji hipotesis dalam penelitian ini dilakukan sebagai berikut.

- Menghitung rata-rata pretes untuk menentukan kemampuan mahasiswa ke dalam kategori lower group (kelompok rendah bawah), middle group (kelompok sedang/tengah) dan upper group (kelompok tinggi/atas). Banyaknya kelompok rendah/bawah atau kelompok atas/tinggi kira-kira 25\%$27 \%$, sedangkan kelompok menengah/sedang kurang lebih 56\%-50\%.

- Mengolah skor pretes, dan postes untuk melihat gambaran atau deskripsi secara umum.

- Melakukan analisis statistik uji normalitas, uji homogenitas variansi, dan uji rata-rata dari distribusi skor pretes dan postes.

- Melakukan pembahasan dari setiap pengujian hipotesis.

- Penarikan kesimpulan.

\section{HASIL DAN PEMBAHASAN}

Hasil pretes dan postes antara kelompok kontrol dan kelompok eksperimen ditunjukkan oleh Tabel 2 di bawah ini.

Tabel 2 Rata-rata Skor Hasil Pretes dan Postes

\begin{tabular}{lccccc}
\hline & \multicolumn{2}{c}{ Pretes } & \multicolumn{2}{c}{ Postes } \\
\cline { 2 - 3 } \cline { 5 - 6 } & Eksperimen & Kontrol & Eksperimen & Kontrol \\
\hline Rendah & 4,5556 & 4,5556 & 27,3333 & 22,3333 \\
Sedang & 8,9500 & 8,9524 & & 41,0500 & 34,0952 \\
Tinggi & 12,5556 & 12,8889 & 53,5556 & 48,6667 \\
Rata-rata & 8,7632 & 8,8462 & & 40,7632 & 34,7436 \\
\hline
\end{tabular}




\section{Skor Hasil Pretes}

Deskripsi data hasil pretes disajikan sebagai berikut.

Tabel 3. Deskripsi Skor Pretes Kelompok Eksperimen dan Kelompok Kontrol

\begin{tabular}{lcccccc}
\hline \multicolumn{1}{c}{ Kelompok } & $N$ & Minimum & Maximum & Mean & $\begin{array}{c}\text { Std. } \\
\text { Deviation }\end{array}$ & Variance \\
\hline Eksperimen & 38 & 3,00 & 15,00 & 8,7632 & 3,07065 & 9,429 \\
Kontrol & 39 & 3,00 & 15,00 & 8,8462 & 3,10804 & 9,660 \\
\hline
\end{tabular}

Berdasarkan Tabel 3 di atas, ratarata skor pretes kelompok eksperimen dan kelompok kontrol masing-masing 8,7632 dan 8,8462 dengan skor maksimum dan minimum masing-masing adalah sama, yaitu 15,00 dan 3,00. Secara matematis, rata-rata skor pretes dari kedua kelompok itu memang berbeda. Namun demikian, apakah rata-rata kemampuan pemahaman konsep matematis kedua kelompok tersebut berbeda? Hal ini akan ditunjukkan dengan uji secara statistik berdasarkan uji hipotesis tentang perbedaan rata-rata skor pretes tentang pemahaman konsep matematis di bawah. Namun, sebelum uji hipotesis tentang perbedaan skor dilaksanakan, ada persyaratan yang harus dipenuhi, yakni uji normalitas dan homogenitas.

Untuk menguji normalitas kedua kelompok sebelum diberikan perlakuan yang berbeda, ditunjukkan oleh hasil perhitungan komputer pada Tabel 4 di bawah ini. Hipotesis uji normalitas tentang hal ini disajikan sebagai berikut.

$\mathrm{H}_{0}$ : Skor pretes pada kelompok eksperimen dan kelompok kontrol terdistribusi normal.

$\mathrm{H}_{\mathrm{a}}$ : Skor pretes pada kelompok eksperimen dan kelompok kontrol tidak terdistribusi normal.

Taraf signifikansi $(\alpha)$ yang digunakan dalam uji hipotesis ini sama dengan 5\%. Kriteria pengambilan keputusan adalah jika nilai signifikansi hasil perhitungan (disingkat Sig.) atau nilai probabilitas lebih besar dari taraf signifikansi ( $\alpha$ ) maka $\mathrm{H}_{0}$ diterima. Dengan menggunakan komputer, hasil perhitungan uji normalitas skor hasil pretes disajikan sebagai berikut.

Tabel 4. Tests of Normality Distribusi Skor Pretes

\begin{tabular}{llcccccc}
\hline & \multirow{2}{*}{ Model PBM } & \multicolumn{3}{c}{ Kolmogorov-Smirnov(a) } & \multicolumn{3}{c}{ Shapiro-Wilk } \\
& & Statistic & $d f$ & Sig. & Statistic & $d f$ & Sig. \\
\hline \multirow{2}{*}{ Pretes } & Eksperimen & 0,110 & 38 & $0,200\left(^{*}\right)$ & 0,972 & 38 & 0,445 \\
& Kontrol & 0,085 & 39 & $0,200\left(^{*}\right)$ & 0,977 & 39 & 0,578 \\
\hline
\end{tabular}

* This is a lower bound of the true significance.

a Lilliefors Significance Correction 
Berdasarkan Tabel 4 di atas, nilai Sig. pada uji Kolmogorov-Smirnov pada kelompok eksperimen dan kelompok kontrol masing-masing sama dengan 0,200 dan oleh komputer diberi tanda *) yang berarti bahwa nilai tersebut signifikan, sedangkan nilai-nilai Sig. pada uji Shapiro-Wilk masing-masing 0,445 dan 0,578. Nilai-nilai Sig. pada Kolmogorov-Smirnov maupun Shapiro-Wilk tersebut semuanya lebih besar dari 0,05. Karena itu, $\mathrm{H}_{0}$ diterima. Jadi, dapat disimpulkan bahwa distribusi skor pretes kelompok eksperimen dan kelompok kontrol terdistribusi normal.

Untuk merepresentasikan kenormalan distribusi skor pretes secara gra-

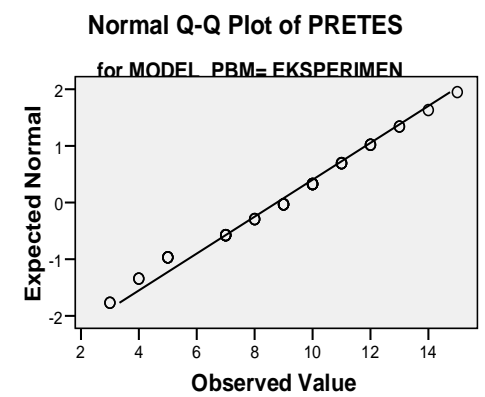

fik, di bawah ini disajikan grafik Q-Q Plot untuk masing-masing kelompok sampel penelitian. Gambar 1 di bawah merupakan grafik Q-Q Plot memperlihatkan bahwa sebagian besar skor pretes pada kelompok ekperimen atau kelompok kontrol berada pada atau di sekitar garis lurus. Santoso (155:2007) menyatakan bahwa suatu data akan terdistribusi normal jika sebagian besar data tersebut terletak pada atau tersebar di sekitar garis lurus yang membentang dari kiri bawah ke kanan atas. Garis lurus tersebut yang berasal dari nilainilai Z skor pretes.

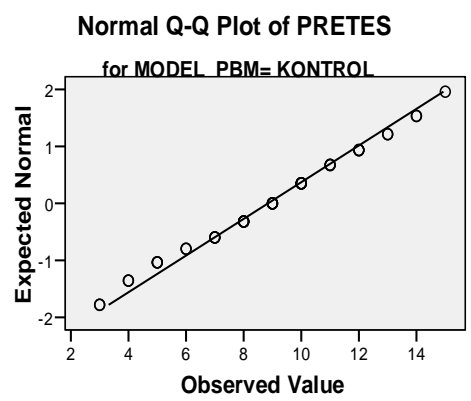

Gambar 1. Normal Q-Q Plot Distribusi Skor Pretes Kelompok Eksperimen dan Kontrol

Selanjutnya, di bawah ini ditunjukkan uji hipotesis dan analisis homogenitas skor pretes. Hipotesis tentang hal ini dikemukakan sebagai berikut.

$\mathrm{H}_{0}$ : Kelompokeksperimendan kelompok kontrol mempunyai variansi skor pretes yang homogen.

$\mathrm{H}_{\mathrm{a}}$ : Kelompokeksperimen dan kelompok kontrol mempunyai variansi skor pretes yang tidak homogen.
Taraf signifikansi $(\alpha)$ yang digunakan dalam uji hipotesis ini sama dengan 5\%. Kriteria pengambilan keputusan adalah jika nilai Sig. atau nilai probabilitas lebih besar dari taraf signifikansi $(\alpha)$, maka $\mathrm{H}_{0}$ diterima. Hasil perhitungan uji homogenitas variansi skor pretes dengan menggunakan komputer disajikan pada Tabel 5 di bawah ini. 
Tabel 5. Test of Homogeneity of Variances Skor Pretes

\begin{tabular}{crrc}
\hline Levene Statistic & $d f 1$ & $d f 2$ & Sig. \\
\hline 0,000 & 1 & 75 & 0,993 \\
\hline
\end{tabular}

Berdasarkan Tabel 5 di atas, nilai Lavene Statistic sama dengan 0,000, dan nilai probabilitas atau nilai Sig. sama dengan 0,993. Dengan demikian, nilai probabilitas ini lebih besar dari 0,05. Oleh karena itu, $\mathrm{H}_{0}$ diterima. Jadi, skor pretes kelompok eksperimen dan kelompok kontrol mempunyai variansi yang homogen.

Penelitian ini merupakan penelitian parametrik. Oleh karena itu, uji normalitas dan homogenitas variansi skor pretes pada kelompok eksperimen dan kelompok kontrol perlu dilakukan lebih dulu sebelum uji hipotesis lainnya, karena hal ini merupakan persyaratan yang harus dipenuhi dalam statistika parametrik.

Setelah distribusi skor pretes pada kelompok eksperimen dan kelompok kontrol terbukti mempunyai variansi homogen dan berdistribusi normal, maka langkah penelitian selanjutnya adalah melakukan uji perbedaan ratarata skor pretes pada kedua kelompok tersebut. Untuk keperluan ini, peneliti menggunakan ANOVA (Analysis of $\mathrm{Va}$ - riance). Langkah uji perbedaan rata-rata rata-rata skor pretes kelompok eksperimen dan kelompok kontrol sebagai berikut.

$\mathrm{H}_{0}$ : Kelompok eksperimen dan kelompok kontrol mempunyai rata-rata yang sama $\left(\mu_{\mathrm{eks}}=\mu \mathrm{ktrl}\right)$.

$\mathrm{H}_{\mathrm{a}}$ : Kelompok eksperimen dan kelompok kontrol mempunyai rata-rata yang tidak sama ( $\left.\mu_{\mathrm{eks}} \neq \mu \mathrm{ktrl}\right)$.

Taraf signifikansi $(\alpha)$ yang digunakan dalam uji kipotesis ini adalah 5\% dan kriteria pengambilan keputusannya adalah jika nilai Sig. atau nilai probabilitas lebih besar dari taraf signifikansi $(\alpha)$, maka Ho diterima.

Berdasarkan Tabel 3 di atas, ratarata kelas yang akan dijadikan kelompok eksperimen sama dengan 8,7632, sedangkan kelas yang akan diambil sebagai kelompok kontrol sama dengan 8,8462 . Secara matematis, kedua kelompok tersebut memiliki rata-rata kemampuan yang berbeda. Untuk kepentingan uji hipotesis tentang perbedaan ratarata, di bawah ini disajikan Tabel 6 hasil perhitungan komputer tentang uji perbedaan rata-rata skor hasil pretes kelompok eksperimen dan kelompok kontrol.

Tabel 6. ANOVA Skor Pretes

\begin{tabular}{lrrrrr}
\hline \multicolumn{1}{c}{ Pretes } & Sum of Squares & \multicolumn{1}{c}{$d f$} & Mean Square & \multicolumn{1}{c}{ S } & \multicolumn{1}{c}{ Sig. } \\
\hline Between Groups & 0,133 & 1 & 0,133 & 0,014 & 0,907 \\
Within Groups & 715,945 & 75 & 9,546 & & \\
Total & 716,078 & 76 & & & \\
\hline
\end{tabular}


Berdasarkan Tabel 6 di atas, nilai probabilitas atau nilai Sig. sama dengan 0,907 . Dengan demikian, nilai probabilitas ini lebih besar dari 0,05. Oleh karena itu, $\mathrm{H}_{0}$ diterima. Jadi, dapat ditarik kesimpulan bahwa sebelum penelitian dilaksanakan atau dengan kata lain sebelum kedua kelompok diberi perlakuan yang berbeda, diperoleh hasil ratarata kemampuan awal mahasiswa dalam hal pemahaman konsep matematis antara kedua kelompok relatif sama. Dengan demikian, penelitian dapat dilanjutkan dengan pemberian model pembelajaran yang berbeda antara kedua kelompok dan kemudian hasilnya dianalisis dengan statistik parametrik.

\section{Pembahasan Skor Hasil Postes}

Deskripsi data hasil postes disajikan sebagai berikut

Tabel 7. Deskripsi Skor Postes Kelompok Eksperimen dan Kelompok Kontrol

\begin{tabular}{lcccccc} 
Kelompok & $N$ & Mean & Std. Deviation & Std. Error & Minimum & Maximum \\
\hline Eksperimen & 38 & 40,7632 & 9,96327 & 1,61626 & 20,00 & 60,00 \\
Kontrol & 39 & 34,7436 & 10,11699 & 1,62002 & 20,00 & 60,00 \\
Total & 77 & 37,7143 & 10,42499 & 1,18804 & 20,00 & 60,00
\end{tabular}

Berdasarkan Tabel 7 di atas, rata40,7632 dan 34,7436 dengan skor maksirata skor postes kelompok eksperimen dan kelompok kontrol masing-masing mum dan minimum masing-masing sama, yaitu 60,00 dan 20,00.

Tabel 8. Tests of Normality Distribusi Skor Postes

\begin{tabular}{llcccccc}
\hline \multirow{2}{*}{ Model PBM } & \multicolumn{3}{c}{ Kolmogorov-Smirnov $(a)$} & \multicolumn{3}{c}{ Shapiro-Wilk } \\
\cline { 3 - 8 } & Statistic & $d f$ & Sig. & Statistic & $d f$ & Sig. \\
\hline \multirow{2}{*}{ Postes } & Eksperimen & 0,089 & 38 & $0,200\left(^{*}\right)$ & 0,971 & 38 & 0,412 \\
& Kontrol & 0,094 & 39 & $0,200\left(^{*}\right)$ & 0,964 & 39 & 0,233 \\
\hline
\end{tabular}

* This is a lower bound of the true significance.

a Lilliefors Significance Correction

Berdasarkan Tabel 8 di atas, hasil perhitungan nilai Sig. uji KolmogorovSmirnov pada kelompok eksperimen maupun kelompok kontrol sama dengan 0,200. Pada pengujian ShapiroWilk, masing-masing kelompok mempunyai nilai Sig. 0,412 dan 0,233. Nilainilai Sig. atau nilai-nilai probabilitas di atas semuanya lebih besar dari 0,05. Oleh karena itu, $\mathrm{H}_{0}$ diterima. Jadi, skor postes pada kelompok eksperimen dan kelompok kontrol terdistribusi normal. Selanjutnya, apabila skor postes dari masing-masing kelompok disajikan dalam bentuk grafik, maka data skor ter- 
sebut sebagian besar berada disekitar garis lurus seperti Gambar 2 berikut.
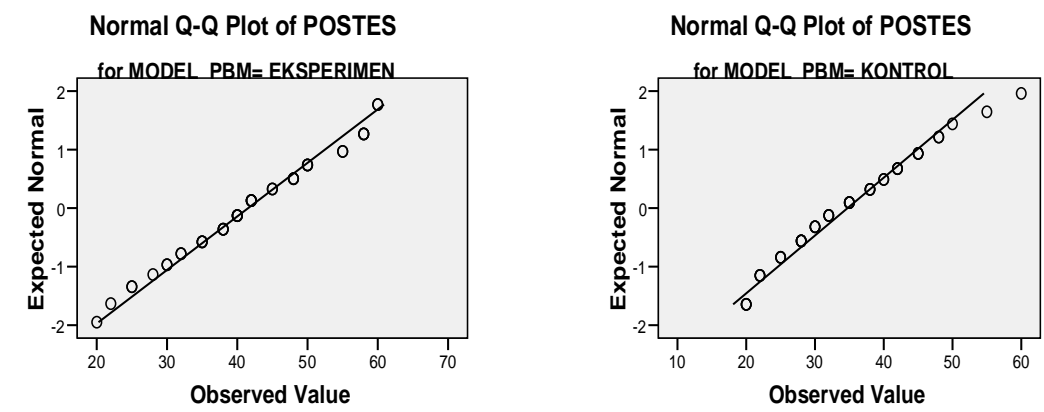

Gambar 2. Normal Q-Q Plot Distribusi Skor Postes Kelompok Eksperimen dan Kontrol

Untuk menunjukkan homogenitas skor postes tentang pemahaman konsep matematis, di bawah ini disajikan hasil perhitungan komputer sebagai berikut.

Tabel 9. Test of Homogeneity of Variances Skor Postes

\begin{tabular}{cccc} 
Levene Statistic & $d f 1$ & $d f 2$ & Sig. \\
\hline.-083 & 1 & 75 & 0,774 \\
\hline
\end{tabular}

Berdasarkan Tabel 9 di atas, Lavene Statistic sama dengan 0,083 , dengan nilai probabilitas atau nilai Sig. sama dengan 0,774 . Dengan demikian, nilai probabilitas ini lebih besar dari 0,05 se-

Tabel 10. Anova Skor Postes

\begin{tabular}{lrrrrr}
\hline Postes & Sum of Squares & $d f$ & Mean Square & \multicolumn{1}{l}{$F$} & \multicolumn{1}{c}{ Sig. } \\
\hline Between Groups & 697,410 & 1 & 697,410 & 6,917 & 0,010 \\
Within Groups & 7562,304 & 75 & 100,831 & & \\
Total & 8259,714 & 76 & & & \\
\hline
\end{tabular}

Berdasarkan Tabel 10 di atas, nilai probabilitas atau nilai Sig. sama dengan 0,010 . Ini berarti bahwa nilai probabilitas ini lebih kecil dari pada 0,05 se- hingga $\mathrm{H}_{0}$ diterima. Jadi, skor postes kelompok eksperimen dan kelompok kontrol mempunyai variansi yang homogen.

Untukmenunjukkan apakah kelompok eksperimen dan kelompok kontrol setelah masing-masing melaksanakan pembelajaran dengan menggunakan pendekatan yang berbeda benar-benar mempunyai perbedaan kemampuan pemahaman konsep, maka perlu dilakukan uji hipotesis terhadap perhitungan Anova skor postes seperti yang ditunjukkan pada Tabel 10 di bawah. hingga $\mathrm{H}_{0}$ ditolak. Jadi, dapat ditarik kesimpulan bahwa setelah penelitian dilaksanakan atau setelah kedua kelompokdiberikan model pembelajaran yang 
berbeda, rata-rata kemampuan mahasiswa pada kelompok eksperimen dan kelompok kontrol adalah tidak sama.

Berdasarkan Tabel 10, rata-rata skor postes kelompok eksperimen sama dengan 40,7632, sedangkan kelompok kontrol mempunyai rata-rata 34.7436 . Dengan demikian, jika hal ini dibandingkan dengan skor pretes, maka gain atau perolehan kelompok eksperimen sama dengan 32.0000 jauh lebih tinggi dari pada gain kelompok kontrol yang besarnya sama dengan 25.8974. Selanjutnya, untuk melihat secara jelas mengenai kelom-pok mana yang mempunyai perbedaan secara signifikan, di bawah ini disajikan hasil perhitungan pada Tabel 11 berikut.

Tabel 11. Subset Perbedaan Kelompok Eksperimen dan Kontrol

\begin{tabular}{lccc}
\hline Kelompok & $N$ & Subset for alpha $=0,05$ \\
\cline { 2 - 4 } & 1 & 2 & 1 \\
\hline Kontrol & 39 & 34,7436 & \\
& 38 & & 40,7632 \\
Eksperimen & & & 0,946 \\
Sig. & & 1,000 & 0 \\
\hline
\end{tabular}

Berdasarkan Tabel 11 di atas, ditunjukkan bahwa secara signifikan (yakni 1,000 dan 0,946 dan keduanya lebih besar dari pada 0,05) kelompok eksperimen dan kelompok kontrol berada subset yang berbeda. Hal ini membuktikan bahwa kedua kelompok tersebut mempunyai rata-rata kemampuan postes yang berbeda. Oleh karena itu, dapat disimpulkan bahwa mahasiswa yang diajar dengan menggunakan program aplikasi multimedia interaktif Elementary Statistics (A Step by Step Approach) model Allan G. Bluman mempunyai pemahaman konsep matematis yang lebih tinggi daripada mahasiswa yang diajar secara konvensional.

Untuk mengetahui ada tidaknya interaksi antara model pembelajaran dan skor hasil postes tentang pemahaman konsep, digunakan uji Anova Dua Jalur. Hipotesis-hipotesis yang berkenaan dengan masalah ini sebagai berikut.

\section{- Kemampuan (A)}

$\mathrm{H}_{0}$ : Tidak ada perbedaan yang signifikan mengenai rata-rata skor postes antara mahasiswa yang berkemampuan rendah dengan yang berkemampuan tinggi $(\mu$ Rendah $=$ $\mu$ Tinggi).

$\mathrm{H}_{\mathrm{a}}$ : Ada perbedaan yang signifikan mengenai rata-rata skor postes antara mahasiswa yang berkemampuan rendah dengan yang berkemampuan tinggi.

Selanjutnya, data hasilperhitungan komputer disajikan dalam Tabel 12 berikut. 
Tabel 12. ANOVA Dua Jalur Skor Postes Pemahaman Konsep Matematis Dependent Variable:POSTES

\begin{tabular}{lrrrrc}
\hline Source & Type III Sum of Squares & df & Mean Square & \multicolumn{1}{c}{ F } & Sig. \\
\hline Corrected Model & $6934,733^{\mathrm{a}}$ & 5 & 1386,947 & 74,320 & 0,000 \\
Intercept & 95089,405 & 1 & 95089,405 & $5,095 \mathrm{E} 3$ & 0,000 \\
KEMAMPUAN (A) & 6217,755 & 2 & 3108,877 & 166,591 & 0,000 \\
KELOMPOK (B) & 523,386 & 1 & 523,386 & 28,046 & 0,000 \\
KEMAMPUAN * & 19,390 & 2 & 9,695 & 0,519 & 0,597 \\
KELOMPOK (A*B) & 1324,982 & 71 & 18,662 & & \\
Error & 117782,000 & 77 & & & \\
Total & 8259,714 & 76 & & & \\
Corrected Total & & & & & \\
\hline
\end{tabular}

a. $R$ Squared $=0,840$ (Adjusted $R$ Squared $=0,828$ )

Karena nilai Sig. pada source "KEMAMPUAN" lebih kecil daripada 0,05, maka $\mathrm{H}_{0}$ ditolak. Hal ini berarti terdapat perbedaan yang signifikan mengenai hasil postes tentang pemahaman konsep matematis antara mahasiswa yang kemampuannya rendah dengan mahasiswa yang kemampuannya tinggi. Hal ini menunjukkan bahwa setelah pembelajaran dengan model yang berbeda selesai dilaksanakan, mahasiswa dalam kelompok pandai (tinggi) benarbenarmemiliki kemampuan konsep matematis yang lebih tinggi daripada mahasiswa dalam tidak pandai (rendah).

\section{- Kelompok model pembelajaran (B)}

Nilai Fhitung untuk kelompok model pembelajaran (B) pada Tabel 12 yaitu 28,046 dengan nilai Sig. sama dengan 0,000 .

$\mathrm{H}_{0}$ : Tidak ada perbedaan yang signifikan mengenai rata-rata skor postes antara mahasiswa yang diajar dengan model pembelajaran dalam kelompok eksperimen dan konvensional $(\mu$ Eksp $=\mu$ Ktrl $)$.
$\mathrm{H}_{\mathrm{a}}$ : Ada perbedaan yang signifikan mengenai rata-rata skor postes antara mahasiswa yang diajar dengan model pembelajaran dalam kelompok eksperimen dan konvensional.

Karena nilai Sig. lebih kecil daripada 0,05, maka $\mathrm{H}_{0}$ ditolak. Dengan demikian, terdapat perbedaan yang signifikan mengenai kemampuan pemahaman konsep matematis antara mahasiswa dalam kelompok eksperimen dan kelompok kontrol. Dalam hal ini, mahasiswa dalam kelompok eksperimen memiliki skor postes yang jauh lebih tinggi daripada skor postes mahasiswa pada kelompok kontrol.

- Interaksi antara kemampuan pemahaman konsep dengan kelompok model pembelajaran $(A \times B)$

Untuk menyelidiki ada tidaknya interaksi antara model pembelajaran terhadap kemampuan mahasiswa (rendah dan tinggi), hipotesis nihil dan hipotesis alternatif adalah sebagai berikut.

$\mathrm{H}_{0}$ : Tidak ada perbedaan yang signifikan mengenai selisih rata-rata skor 
postes antara mahasiswa dalam kelompok eksperimen dan konvensional ditinjau dari kemampuan mahasiswa (rendah, tinggi).

$\mu$ EkspRdh $-\mu$ KtrlRdh $=\mu$ EkspTinggi $-\mu$ KtrlTinggi, atau

$\mu$ EkspRdh $-\mu$ EkspTinggi $=\mu$ KtrlRdh $-\mu$ KtrlTinggi

$\mathrm{H}_{\mathrm{a}}$ : Ada perbedaan yang signifikan mengenai selisih rata-rata skor postes antara mahasiswa dalam kelompok eksperimen dan konvensional ditinjau dari kemampuan mahasiswa (rendah, tinggi).

Berdasarkan Tabel 12 di atas, diperoleh nilai Fhitung untuk $\mathrm{A} \times \mathrm{B}$ sebesar 0,519 dengan nilai Sig. 0,597. Karena nilai Sig. lebih besardaripada 0,05, maka $\mathrm{H}_{0}$ diterima. Hal ini berarti bahwa tidak terdapat perbedaan yang signifikan mengenai selisih rata-rata skor postes pemahaman konsep matematis antara mahasiswa yang diajar dengan menggunakan program aplikasi multimedia interaktif Elementary Statistics (A Step by Step Approach) model Allan G. Bluman dengan mahasiswa yang diajar secara konvensional pada mahasiswa yang kemampuannya rendah atau tinggi. Dengan kata lain, tidak terdapat pengaruh yang signifikan antara kemampuan mahasiswa terhadap kedua model pembelajaran tersebut. Artinya, mahasiswa yang kemampuan rendah atau tinggi tetap akan mempunyai kemampuan rendah atau tinggi meskipun diajar dengan model pembelajaran yang dilaksanakan oleh kelompok eksperimen. Ketiadaan interaksi antara kemampuan mahasiswa dan model pembelajaran ditunjukkan oleh kedua garis lurus yang relatif sejajar pada Gambar 3 di bawah ini.

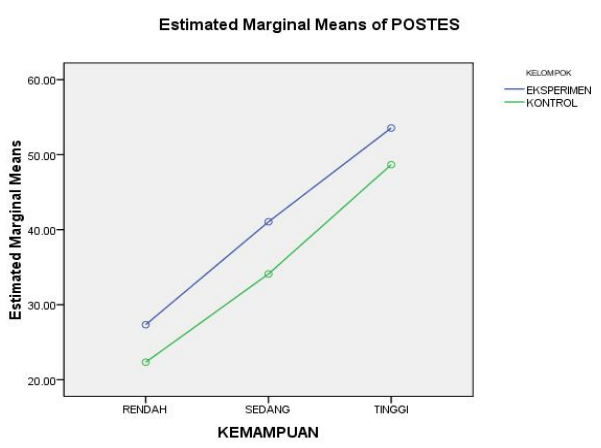

Gambar 3. Interaksi Kemampuan Mahasiswa dan Model PBM

\section{PENUTUP}

Terdapat perbedaan yang signifikan mengenai peningkatan pemahaman konsep matematis antara mahasiswa yang diajar dengan menggunakan alat bantu komputer dengan mahasiswa yang diajar secara konvensional. Dalam hal ini, gain pemahaman konsep matematis dari kelompok eksperimen lebih tinggi daripada gain kelompok kontrol. Oleh karenaitu, dapat disimpulkan bahwa mahasiswa yang diajar dengan menggunakan alat bantu komputer, yakni dengan menggunakan program aplikasi multimedia interaktif Elementary Statistics (A Step by Step Approach) model Allan G. Bluman mempunyai pemahaman konsep matematik yang lebih tinggi daripada mahasiswa yang diajar secara konvensional.

\section{UCAPAN TERIMA KASIH}

Alhamdulillahirobbil'alamin sayaucapkan terima kasih kepada tim Redaktur danstafJurnal Cakrawala Pendidikan Universitas Negeri Yogyakarta yang telah berkenan menerima dan mempublikasikan artikel ini. Mudah-mudahan artikel 
ini dapat menambah pencerahan para pembaca dan bermanfaat bagi perkembangan pendidikan di Indonesia.

\section{DAFTAR PUSTAKA}

Bluman, Allan G. 2004. Elementary Statistics (A Step by Step Approach). New York: McGraw-Hill Companies.

Departeman Pendidikan Nasional. 2003. Pedoman Khusus Pengembangan Sistem Penilaian Berbasis Kompetensi SMP. Jakarta: Depdiknas.

Departemen Pendidikan Nasional. 2004. Strategi Jangka Panjang Pendidikan Tinggi 2003-20010 (HELTS). Jakarta: Depdiknas.

Departemen Pendidikan Nasional. 2005. Rencana Strategis Departemen Pendidikan Nasional Tahun 2005-2009. Jakarta: Depdiknas.

Hillel, Joel. 2001. "Computer Algebra Systems in the Learning and Teaching of Linear Algebra: Some Examples", dalam Derek Holton (Ed.). The Teaching and Learning of Mathematics at University Level. Dordrecht: Kluwer Academic Publishers.
Myers, Sharon, L., Myers, Raymond H., Walpole, Ronald E. 2002. Probability $\mathcal{E}$ Statis-tics for Engineers \& Scientists. New Jersey. PrenticeHall Inc.

Santoso, S. 2007. Menguasai Statistik di Era Informasi dengan SPSS 15. Jakarta: PT Elex Media Komputindo.

Sarama, J.\& Clements, H.D. 2001. Computers in Early Childhood Mathematics. USA: University at Buffalo.

Sumarmo, U. 1987. "Kemampuan Pemahaman dan Penalaran Matematik Siswa SMA Dikaitkan dengan Penalaran Logik Siswa dan Beberapa Unsur Proses BelajarMengajar". Disertasi Doktor pada PPS-UPI Bandung: Tidak dipublikasikan.

Yushau, B., Miji, A. and Wessels. 2003. Creativity and Computer in Teaching and Learning of Mathematics. Saudi Arabia: King Fahd University of Petrolium \& Mineral [Online]. (www.kfupm.edu.sa/ math/). Diunduh tanggal 5 November 2004. 